\title{
PENGARUH MODEL PROBLEM BASED LEARNING TERHADAP HASIL BELAJAR SISWA PADA MATERI CAHAYA DI KELAS VIII SMP NEGERI 2 PERBAUNGAN T.P 2015/2016
}

\author{
Taufik Mawardi Sinaga dan Rahmatsyah \\ Jurusan Fisika FMIPA Universitas Negeri Medan \\ Jalan Willem Iskandar Pasar V Medan, Sumatera Utara \\ taufikardi81@yahoo.com
}

\begin{abstract}
ABSTRAK
Tujuan penelitian ini untuk mengetahui hasil belajar siswa yang diajarkan menggunakan model problem based learning terhadap hasil belajar siswa pada materi cahaya di kelas VIII SMP Negeri 2 Perbaungan T.P. 2015/2016. Populasi dalam penelitian ini adalah siswa kelas VIII SMP Negeri 2 Perbaungan. Jenis penelitian ini adalah quasi experiment dengan pretest-posttest control group design. Pengambilan sampel dilakukan dengan cara cluster random sampling dengan sampel terdiri dari dua kelas yaitu kelas VIII-4 (sebagai kelas eksperimen) dan kelas VIII-1 (sebagai kelas kontrol) yang masing-masing berjumlah 32 siswa. Instrumen bentuk tes essay jumlah soal 10 item. Hasil uji hipotesis menggunakan uji beda diperoleh bahwa ada pengaruh model problem based learning terhadap hasil belajar siswa pada materi cahaya di kelas VIII SMP Negeri 2 Perbaungan.
\end{abstract}

Kata Kunci: Problem Based Learning, hasil belajar, cahaya

\begin{abstract}
The purpose of this study to determine the learning outcomes of the students who were taught using problem based learning model to the student learning outcomes in light of the material in the class of SMP Negeri 2 Perbaungan TP 2015/2016. The population in this study is the eighth grade students of SMP Negeri 2 Perbaungan. This research is quasiexperiment with pretest-posttest control group design. Sampling was done by cluster random sampling with the sample consisted of two classes: a class VIII-4 and VIII-1 experiment as control classes, aech of which is 32 students. Instrumens essay test from number about 10 items. Result of hypothesis tensting using different test showed that there is influence of problem based learning of student learning outcomes in light of the material in class VIII semester of SMP Negeri 2 Perbaungan.
\end{abstract}

Keywords : problem based learning, learning outcomes, light

\section{PENDAHULUAN}

Pendidikan sebagai salah satu sektor yang paling penting dalam pembangunan nasional dan dijadikan andalan utama untuk berfungsi semaksimal mungkin dalam meningkakan kualitas hidup dan sumberdaya manusia Indonesia. Pendidikan yang dikelola dengan tertib, teratur, efektif, dan efisien akan mampu mempercepat proses pembudayaan bangsa pada penciptaan kesejahteraan umum dan pencerdasan kehidupan bangsa Indonesia (Ihsan, 2011).

Data hasil pengamatan dilapangan oleh peneliti saat melakukan Program Pengalaman Lapangan Terpadu (PPLT) di 
SMP Negeri 2 Perbaungan, banyak siswa yang mengatakan pelajaran fisika kurang menarik untuk dipelajari, karena fisika penuh dengan rumus - rumus dan hitung hitungan yang sulit, akibatnya pemahaman konsep fisika siswa masih rendah dan mengakibatkan hasil belajar fisika rendah. Hal ini terlihat dari nilai ujian siswa pada ulangan harian masih banyak yang mendapatkan nilai di bawah Kreteria Ketuntasan Minimum (KKM) yakni 78, dari 36 siswa hanya 5 siswa yang mencapai nilai di atas KKM selebihnya tidak mencapai KKM. Salah satu yang menyebabkan hasil belajar siswa rendah adalah ketika belajar guru cenderung masih menggunakan pembelajaran yang berpusat pada guru dan proses pembelajaran guru hanya menjelaskan materi, menyampaikan rumus, member soal, penugasan dan siswa tidak pernah melakukan praktikum, sehingga siswa dalam pembelajaran menjadi penerima informasi pasif.

Salah satu cara untuk mengatasi ketidak efektifan proses pembelajaran adalah dengan mengubah model pembelajaran tradisional menjadi model pembelajaran yang berpusat pada keaktifan siswa. Model pembelajaran pada saat ini sudah banyak yang berpusat pada siswa dalam proses pembelajaran, misalnya adalah model problem based learning (PBL). PBL termasuk model pembelajaran yang dapat memacu semangat setiap siswa secara aktif ikut terlibat dalam pengalaman belajarnya, merupakan salah satu alternatif model pembelajaran yang memungkinkan dikembangkannya keterampilan berpikir siswa (penalaran, komunikasi, dan koneksi) dalam memecahkan masalah (Rusman, 2012).

\section{METODE PENELITIAN}

Penelitian ini dilakukan di kelas VIII SMP Negeri 2 Perbaungan semester genap Tahun Pelajaran 2015/2016. Populasi dalam penelitian ini adalah seluruh siswa kelas VIII SMP Negeri 2 Perbaungan. Sampel penelitian adalah sebagian dari populasi. Sampel dalam penelitian ini 2 kelas yang diambil secara cluster random sampling yaitu penarikan sampel dengan proses pengacakan yang disajikan sebagai 1 kelas eksperimen $\left(\mathrm{X}_{1}\right)$ dengan model problem based learning dan 1 kelas kontrol $\left(\mathrm{X}_{2}\right)$ dengan model pembelajaran konvensional dan diperoleh kelas VIII-1 sebagai kelas kontrol dengan jumlah siswa 32 orang dan kelas VIII-4 sebagai kelas eksperimen dengan jumlah siswa 32 orang. Penelitian ini melibatkan dua kelas yaitu kelas eksperimen dan kelas kontrol yang diberi perlakuan berbeda. Model problem based learning di kelas eksperimen, sedangkan pada kelas kontrol menggunakan pembelajaran konvensional.

Tes hasil belajar terlebih dahulu distandarisasi dengan menggunakan uji validitas isi oleh dua orang dosen. Setelah itu peneliti memberikan pretes pada kedua kelas dan mendapatkan hasil pretes kemudian dilakukan analisis data denagn uji normalitas dengan uji liliefors dan uji homogenotas dengan uji kesamaan dua varians. Setelah itu di lakukan pengujian hipotesis uji $\mathrm{t}$ dua pihak untuk mengeahui kemampian awal siswa kedua kelompok sampel dalam hal ini kemampuan awal kedua sampel tersebut harus sama. Selajutnya penelii mengajarkan materi pelajaran dengan menggunakan model problem based learning pada kelas eksperimen dan pembelajaran konvensional pada kelas kontrol. Perbedaan hasil akhirnya diketahui dengan menggunakan uji t satu pihak untuk mengetahui pengaruh perlakuan model problem based learning terhadap hasil belajar.

\section{HASIL DAN PEMBAHASAN Hasil Penelitian}

Data yang dideskripsikan pada penelitian ini meliputi data hasil belajar fisika pada materi cahaya, yang diberikan perlakuan berbeda yaitu 1) model problem based learning, 2) pembelajaran dengan menggunakan pembelajaran konvensional.

Hasil belajar distribusi frekuensi data pretes siswa kelas eksperimen dan kontrol dapat ditunjukkan pada Gambar 1 


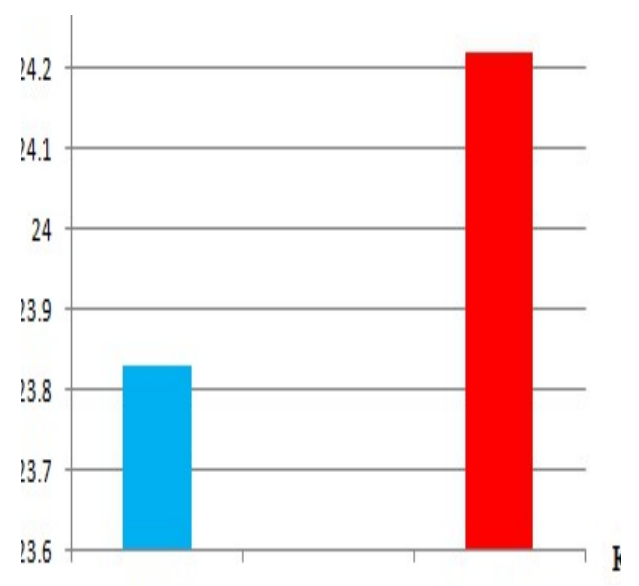

Gambar 1. Diagram Nilai Pretes Berdasarkan Gambar menunjukkan bahwa nilai pretes pada kelas eksperimen dan kelas kontrol memiliki nilai yang sangat rendah namun nilai kelas kontrol sedikit lebih tinggi dibandingkan dengan kelas eksperimen, perbandingan rata-rata nilainya adalah 23,83 dan 24,22.

Distribusi frekuensi data postes siswa kelas eksperimen dan kontrol dapat divisualisasikan dalam digram batang sebagai berikut :

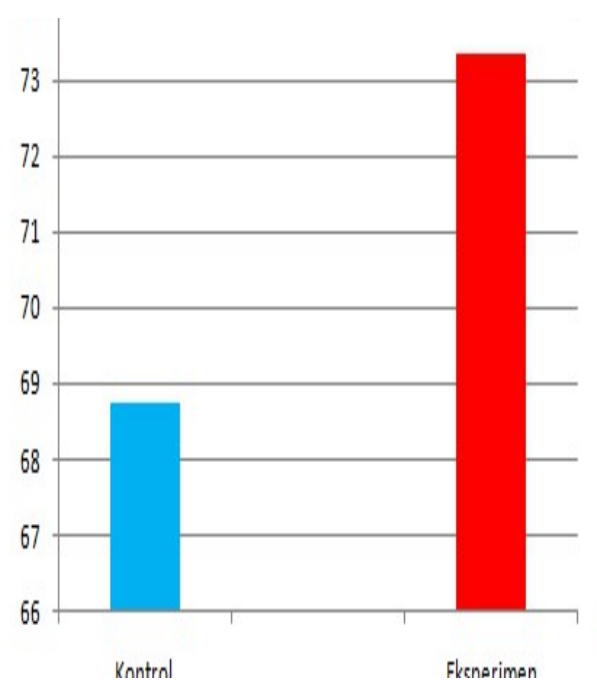

Gambar 2. Diagram nilai postes

Gambar 2 menunjukkan bahwa nilai postes kelas eksoerimen lebih tinggi dari pada nilai postes kelas kontrol. Perbandingan rata-rata nilainya adalah 73,36 dan 68,75. Terdapat peningkatan hasil belajar yang diperoleh pada kedua kelas tersebut tetapi hasil belajar kelas eksperimen lebih baik dibandingkan dengan hasil belajar kelas kontrol.

\section{Pembahasan}

Hasil penelitian menunjukkan bahwa ada pengaruh model problem based learning terhadap hasil belajar siswa. Hal ini dapat terlihat pada data hasil penelitian yang diperoleh bahwa $t_{\text {hitung }}>\quad t_{\text {tabel }}$ $(2,1146>1,6697)$ maka Ho ditolak dan $\mathrm{H}_{\mathrm{a}}$ diterima sehingga ada pengaruh model problem based learning terhadap hasil belajar siswa pada materi cahaya di kelas VIII SMP Negeri 2 Perbaungan. Hasil belajar pada kelas eksperimen jugam mengalami peningkatan dari 23,83 menjadi 73,36 .

Hasil ini juga sesuai dengan peneliti sebelumnya yang telah dilakukan oleh (Hamdani, 2013) menunjukkan hasil belajar dengan model problem based learning mengalami peningkatan dari nilai rerata 67,75 menjadi 76,03 . Selanjunya (Tika, 2010) adanya peningkatan dari nilai rerata 71,20 menjadi 76,90. Selanjunya oleh peneliti (Kharida, 2012) menggunakan model berbasis masalah mengalami peningkatan hasil belajar sebesar $26 \%$.

Peningkatan hasil belajar siswa di kelas eksperimen ini dikarenakan model problem based learning pada saat proses belajar mengajar diberi berbagai masalah yang berkaitan dalam kehidupan sehari-hari sesuai dengan materi pembelajaran dan siswa dituntut untuk bekerja sama dalam memecahkan masalah tersebut dan menemukan sendiri informasi yang berkaitan dengan masalah (Kunarsih dan Sani, 2015). Sehingga siswa lebih termotivasi untuk menemukan solusi dari masalah yang diberikan. Siswa yang dituntut untuk dapat menyelesaikan masalah akan mudah dapat mengingat pelajaran dalam jangka yang panjang sehingga dapat mempengruhi hasil belajarnya.

Hasil belajar juga terlihat pada sikap dan keterampilan pada kelas eksperimen di pertemuan pertama siswa tidak begitu aktif, hal ini dikarenakan siswa masih belum terbiasa dan kurang memahami proses 
pembelajaran yang berbeda dari sebelumnya. Pertemuan kedua dan ketiga sikap dan keterampilan siswa mengalami peningkatan, karena siswa mulai terbiasa dengan pembelajaran berbasis masalah. Hal ini disebabkan semakin sering model problem based learning ini diterapkan, maka siswa pun akan semakin terbiasa dengan model pembelajaran tersebut dan lebih memahami cara pembelajaran berbasis masalah itu, sehingga mampu meningkatkan sikap maupun keterampilan siswa.

Hasil belajar pada kelas kontrol yang diajar dengan menggunakan pembelajaran konvensional diperoleh hasil nilai rata-rata pretesnya 24,23 sedangkan nilai rata-rata postes adalah 68,75 . Hasil belajar kelas kontrol mengalami peningkatan tetapi nilai rata - rata kelas kontrol masih di bawah nilai rata - rata kelas eksperimen hal ini karena pada pembelajaran konvensional, siswa belajar lebih banyak mendengarkan penjelasan di depan kelas dan melaksanakan tugas jika diberikan latihan soal-soal kepada siswa. Sistem konvensional pengajaran yang dilakukan dalam proses belajar mengajar yaitu dengan menggunakan metode ceramah, tanya jawab.

Berdasarkan hasil penilitian model problem based learning telah membuat hasil belajar yang lebih tinggi dibandingkan dengan pembelajaran konvensional, tetapi peneliti juga mengakui bahwa hasil belajar siswa tidak begitu memiliki selisih yang cukup besar Ini disebabkan peneliti mendapatkan kendala-kendala dalam melakukan penelitian. Peneliti banyak memiliki kekurangan dalam melaksanakan penelitian, yaitu waktu yang diperlukan untuk tiap-tiap fase kurang sesuai dengan skenario waktu yang telah direncanakan dalam rencana pelaksanaan pembelajaran (RPP). Selain itu siswa juga kurang memiliki banyak sumber-sumber buku yang dapat membantu dalam menyelesaikan masalah. Peneliti menyarankan untuk peneliti selanjutnya untuk lebih mengoptimalkan waktu yang digunakan agar tidak ada satu fase yang terlewatkan dan peneliti selanjutnya juga harus lebih menyiapkan sumber0-sumber yang lebih banyak sehingga siswa lebih mudah dalam menyelesaikan masalah.

\section{KESIMPULAN}

1. Rata-rata hasil belajar siswa pada kelas eksperimen yang diberi perlakuan dengan model problem based learning mengalami peningkatan dari nilai 23,83 menjadi 73,36. Pada penilaian sikap dan keterampilan pertemuan I hingga pertemuan III mengalami peningkatan.

2. Rata-rata hasil belajar siswa pada kelas kontrol yang diberi perlakuan dengan pembelajaran konvensional (model pembelajaran langsung) adalah 68,74.

3. Pada hasil pengujian hipotesis diperoleh $t_{\text {hitung }}>t_{\text {tabel }}$ yaitu $2,11>1,71$ pada taraf signifikansi $\alpha=0,05$. Hal ini menyatakan terima Hamaka ada pengaruh model problem based learning terhadap hasil belajar siswa pada materi pokok cahaya di SMP Negeri 2 Perbaungan.

\section{DAFTAR PUSTAKA}

Hamdani, D, dan Prasetya, D., (2013), Penerapan Model Problem Based Learning dengan Menggunakan Metode Eksperimen untuk Meningkatkan Hasil Belajar IPA Fisika Siswa Kelas VIII.A SMPN 2 Kota Bengkulu, Prosiding Seminar Nasional Fisika (E-Jurnal) SNF2015.

Ihsan, F., (2011), Dasar - dasar Kependidikan, Rineka Cipta, Jakarta.

Kharida, L, A., (2012), Penerapan Model Pembelajaran Berbasis Masalah Untuk Meningkatkan Hasil Belajar Siswa Pada Pokok Bahasan Elastisitas Bahan, jurnal Pendidikan Fisika Indonesia $5: 83-89$.

Kurniasih, I, dan Sani, B., (2015), Ragam Pengembangan Model Pembelajaran 
Untuk Meningkatkan Profesionalitas Guru, Kata Pena, Jakara.

Rusman., (2012), Model -model Pembelajaran, Rajawali Press, Jakarta.

Ketut, T, I., (2010), Penerapan Problem Based Learning Berorientasi
Penilaian Kinerja Dalam

Pembelajaran Fisika Untuk meningkatkan Kompetensi Kerja Ilmiah Siswa, Jurnal Pendidikan dan Pengajaran UNDIKSHA 3:648-700 